\title{
PERBANDINGAN KEMAMPUAN INKUIRI MAHASISWA PENDIDIKAN GURU SEKOLAH DASAR DALAM PERKULIAHAN SAINS
}

\author{
Chandra Ertikanto \\ Pendidikan Fisika FKIP Universitas Lampung, Indonesia \\ e-mail: chandra.ertikanto@unila.fkip.ac.id
}

Diterima: 21 Desember 2016. Disetujui: 8 April 2017. Dipublikasikan: 28 April 2017

\begin{abstract}
Abstarak: Penelitian ini bertujuan untuk mendeskripsikan kemampuan (pengetahuan dan keterampilan) inkuiri dan tanggapan mahasiswa Pendidikan Guru Sekolah Dasar (PGSD) Universitas Lampung dalam perkuliahan Pendidikan Sains SD. Pelaksanaan penelitiannya dengan model belajar inkuiri secara pemodelan, dimana mahasiswa PGSD berperan sebagai pebelajar SD, dan peneliti sebagai model pengajar SD. Teknik sampling yang digunakan adalah Quota Sampling, yaitu pengambilan sampel secara acak sampai terpenuhi jumlah yang diinginkan. Penelitian ini dilakukan pada 72 orang mahasiswa, dan dilaksanakan mulai Maret sampai Juni 2016.Variabel kemampuan inkuiri diperoleh melalui tes pilihan jamak, dan tanggapan mahasiswa diperoleh melalui angket, Data dianalisis dengan statistik berbantuan komputer. Hasil penelitian menunjukkan bahwa: kemampuan inkuiri mahasiswa PGSD setelah mengikuti perkuliah Sains SD melalui model belajar inkuiri dengan pemodelan, secara signifikan lebih tinggi dibandingkan model belajar inkuiri dengan konvensional. Pada kelompok eksperimen tampak menunjukkan antusias, dan memberikan tanggapan positip, mahasiswa PGSD berharap mata kuliah yang berlabel SD dapat dilaksanakan dengan model belajar inkuiri dengan pemodelan.
\end{abstract}

Kata Kunci: kemampuan inkuiri, pembelajaran sains, model pembelajaran

\section{THE INQUIRY ABILITIES COMPARISON OF THE STUDENTS OF PRIMARY TEACHER TRAINING PROGRAM IN SCIENCE LEARNING}

\begin{abstract}
This research aims to describe the inquiry ability (knowledge and skill) and the response from students of Elementary School Teachers Education (PGSD) Lampung University towards Elementary School (SD) Science Education Lecture. The research is done with modeling the inquiry learning model, where PGSD students play as SD learners and the researcher as SD teacher model. The sampling technique used is Quota Sampling, which means random sampling until fulfilled the number wanted. This research is done on 72 students and starts from March to June 2016. Inquiry ability of variable achieved from the multiple-choice test, and the student's response achieved through questionnaire. The data analysis is using computerized statistics. The research results that the inquiry ability of PGSD students after following SD Science Lecture through modeling inquiry learning model, significantly higher than conventional inquiry learning model. On experimental group seems enthusiasm, and gives a positive response, PGSD students hope the SD labeling lectures can be done by modeling inquiry learning model.
\end{abstract}

(C) 2017 Pendidikan Fisika FTK UIN Raden Intan Lampung

Keywords: inquiry skills, learning model, science learning.

\section{PENDAHULUAN}

Pembelajaran sains di sekolah dasar (SD) pada umumnya belum melibatkan siswa untuk beraktivitas, seperti melakukan eksperimen, kerja kelompok, diskusi, dll. Selain itu, persiapan mengajar sebagian besar calon guru atau mahasiswa Pendidikan Guru Sekolah Dasar (PGSD) kurang menguasai konsep sains, ini tampak dalam kegiatan praktik pembelajaran mahasiswa PGSD ternyata sebagian besar belum sepenuhnya mampu membelajarkan konsep sains dengan metode atau pendekatan pembelajaran yang tepat. Proses sains dalam mempelajari IPA akan berjalan sesuai dengan kaidah yang benar manakala subjek melaksanakan proses tersebut 
memiliki sikap ilmiah yang memadai (Saregar, 2013). Kenyataannya, di lapangan sebagaimana hasil penelitian Ertikanto (2015) bahwa, pembelajaran sains di SD Bandar Lampung dilakukan tidak sciencetific inquiry melainkan secara konvensional, banyak informasi, bersifat hafalan, sehingga hasil belajar sains menjadi rendah bila dibandingkan dengan mata pelajaran lainnya.

Salah satu metode ilmiah untuk memperoleh pengetahuan yang dilakukan di SD dengan cara penyelidiki ilmiah (Saintific inquiri). Sebagaimana disarankan Dewi (2015), bahwa pembelajaran sains sebaiknya dilaksanakan secara pendekatan ilmiah (sciencetific approach), ini dimaksudkan untuk menumbuhkan kemampuan berfikir, bekerja dan bersikap ilmiah serta mengkomunikasikannya sebagai aspek penting dalam kecakapan hidup.

Pembelajaran Sains menggunakan cara penyelidikan dikenal dengan nama inkuiri Matson (2006), bahwa hal-hal yang diajarkan, seharusnya menyerupai apa yang diperbuat oleh seorang ilmuwan sains. Ilmuwan sains mengembangkan teori atau menemukan produk sains melalui kegiatan-kegiatan observasi, klasifikasi, melakukan perhitungan, merumuskan hipotesis, melakukan percobaan dan analisis rasional untuk membuat simpulan. Cara-cara ilmuwan itulah yang disebut inkuiri. Oleh karena itu, inkuiri dapat dikatakan sebagai cara memperoleh pengetahuan yang didapat dari hasil usaha sendiri melalui kegiatan penyelidikan ilmiah, (Nasional, 2003) kerja ilmiah kemampuan-kemampuan merencanakan dan melaksanakan penyelidikan dan berkomunikasi ilmiah. (NRC, 2000) mengatakan pentingnya inkuiri di angkat dan ditekan kan pada pendidikan dasar dan menengah, jadi pembelajaran Sains di SD tidak terlepas dari kegiatan inkuiri. Dalam kegiatan penelitian ini, mahasiswa PGSD yang berlatih mengajar Sains selanjutnya disebut sebagai pembelajar, kemudian dilatih untuk mengembangkan pendekatan ilmiah seperti; mengajukan pertanyaan, menyusun hipotesis, merancang percobaan, mengamati, mengumpulkan data, dan menarik simpulan (Joyce, 2001).

Pada kegiatan pembelajaran Sains SD oleh mahasiswa PGSD ketika latihan mengajar, yang disampaikan lebih banyak ranah kognitif dibanding ranah yang lain. Pola pembelajaran menjadi tidak menarik dan tidak menyenangkan, karena belajar Sains tidak melibatkan hands-on, kemungkinan ini terjadi karena pengetahuan pengajar tentang belajar Sains dengan melibatkan hands-on kurang (Pine, 2006). Demikian juga menurut Ertikanto (2015), dalam penelitiannya, bahwa banyak guru SD menggunakan pembelajaran pola lama, yaitu proses pembelajaran satu arah yang didominasi oleh guru, sehingga pembelajaran kurang menyenangkan. Tampaknya mengajar dilaksanakan hanya sekedar melaksanakan tugas, bukan memberikan pengalaman belajar yang bermakna kepada siswanya. Ini terjadi karena kemampuan mengajar sains dengan model inkuiri kurang dikuasai pengajar.

Temuan Capobianco (2006), menyatakan bahwa melalui metode latihan dalam pembelajaran sains SD, ternyata dapat mengatasi keterbatasan kemampuan pengajar tentang pembelajaran sains dengan model inkuiri. Didukung pula dari penelitian yang dilakukan oleh Hermawan (2014), bila kemampuan merencanakan pembelajaran Sainsdengan model inkuiri baik, ternyata juga dapat meningkatkan kemampuan mengajar Sains di SD secara nyata (riil) dengan baik pula.

Aprilia (2014), dalam penelitian tentang hubungan antara pengetahuan inkuiri terhadap isi materi sains dengan kemampuan untuk membuat perencanaan pembelajaran dengan inkuiri. Hasil 
penelitian menunjukkan bahwa: terdapat hubungan positif yang signifikan antara pengetahuan inkuiri terhadap isi materi sains dengan kemampuan membuat perencanaan pembelajaran dengan inkuiri. Selain dari itu, ditemukan juga bahwa kecakapan dalam membuat perencanaan pembelajaran dengan inkuiri berkontribusi signifikan terhadap kemampuan mengajar Sains dengan inkuiri. Ertikanto (2015) hasil penelitian menunjukkan bahwa kemampuan mengajar melalui penggunaan inkuiri terhadap guru-guru di Nigeria Selatan, diperoleh gambaran bahwa kemampuan mengajar semakin baik dengan menggunakan inkuiri, karena ketika guru mengajar di depan kelas,secara tidak langsung guru juga belajar.

Berdasarkan uraian di atas, peneliti memandang perlu mengembangkan keterampilan inkuiri dan meningkatkan pengetahuan konsep Sains SD bagi mahasiswa PGSD FKIP Universitas Lampung. Peneliti memodelkan pembelajaran yang mengikut sertakan pembelajar (mahasiswa PGSD), proses inkuiri yang dilaksanakan dalam bentuk komunikasi, ini juga merupakan suatu proses bertukarnya pengetahuan (Marx, 2004) jika komunikasi hanya berlangsung satu arah "guru mengajar dan siswa belajar", dalam pola belajar seperti ini instruksi belajar dari guru kurang, karena guru cenderung lebih banyak ceramah, jadi semestinya instruksi dan komunikasi antara guru dan siswa dilakukan dengan benar (Cuevas, 2005) sedang menurut (RuizPrimo, 2007) bahwa komunikasi dalam proses belajar sains dari waktu ke waktu menunjukkan kemajuan pengetahuan bila dilakukan dengan cara inkuiri ilmiah (sciencetific inquiry),yang didalamnya terdapat proses: mengamati, mengumpulkan, mengklasifikasikan dan melakukan eksperimen untuk menarik simpulan.

Masalah dalam penelitian ini adalah: apakah kemampuan inkuiri mahasiswa PGSD setelah mengikuti perkuliah Sains SD melalui model inkuiri dengan pemodelan, lebih tinggi dibandingkan model inkuiri dengan konvensional? dan bagaimana tanggapan mahasiswa PGSD terhadap perkuliahan Sains SD? Hasil penelitian ini diharapkan dapat memberi sumbangan dalam rangka meningkatkan kemampuan inkuiri mahasiswa PGSD. Manfaat lain adalah agar mahasiswa PGSD dapat meningkatkan penguasaan konsep Sains, dan mampu mengajarkan Sains dengan menerapkan pembelajaran secara inkuiri.

\section{METODE PENELITIAN}

Penelitian ini dilaksanakan pada bulan Maret sampai bulan Juni tahun 2016 pada mahasiswa PGSD FKIP Universitas Lampung. Populasi dalam penelitian ini adalah mahasiswa PGSD Universitas Lampung semester 4 berjumlah 200 orang, yang dikenakan Program Persiapan Pengenalan Pembelajaran Kompetensi Akademik (P4KA) di SD, Teknik sampling yang digunakan adalah Quota Sampling (Arikunto, 2008) yaitu dengan memilih mahasiswa peserta P4KA, yang bertempat di SD Kota Bandar Lampung dan berada di pusat kota, semi-kota dan pinggiran-kota, sehingga diperoleh sampel berjumlah 72 mahasiswa. kemudian disesuaikan dengan desain penelitian yaitu dibagi menjadi 2 (dua) kelompok, satu kelompok dijadikan kelas eksperimen dengan jumlah 36 orang, dan satu kelompok lagi adalah kelompok kontrol dengan jumlah 36 orang, rancangan penelitiannya menggunakan Control Group Design (Arikunto, 2008).

Data kemampuan inkuiri dalam perkuliah Sains SD dengan model inkuiri baik dengan pemodelan maupun secara konvensional, diperoleh melalui post-test dengan item tes sebanyak 20 soal dengan bentuk objektif pilihan jamak, dan tanggapan mahasiswa terhadap pola perkuliahan diperoleh melalui angket. 
Seluruh data yang diperoleh kemudian dianalisis dengan statistik program komputer.

Instrumen post-test terlebih dahulu dianalisis dengan analisis butir soal yang meliputi validitas, realibilitas, daya pembeda dan tingkat kesukaran. Soal yang tidak memenuhi salah satu kriteria atau kualitasnya rendah perlu direvisi atau diganti. Kemudian tahap selanjutnya menganalisis data hasil penelitian, yaitu melakukan uji normalitas, homogenitas, dan uji perbedaan dua rata-rata.

\section{HASIL DAN PEMBAHASAN Hasil}

Hasil analisis perbedaan ratarataskor Postest dan skor Pengetahuan pada perkuliah Sains mahasiswa PGSD pada pembelajaran model inkuiri secara pemodelan (kelompok eksperimen) dan secara konvensional (kelompok kontrol) disajikan pada gambar 1 .

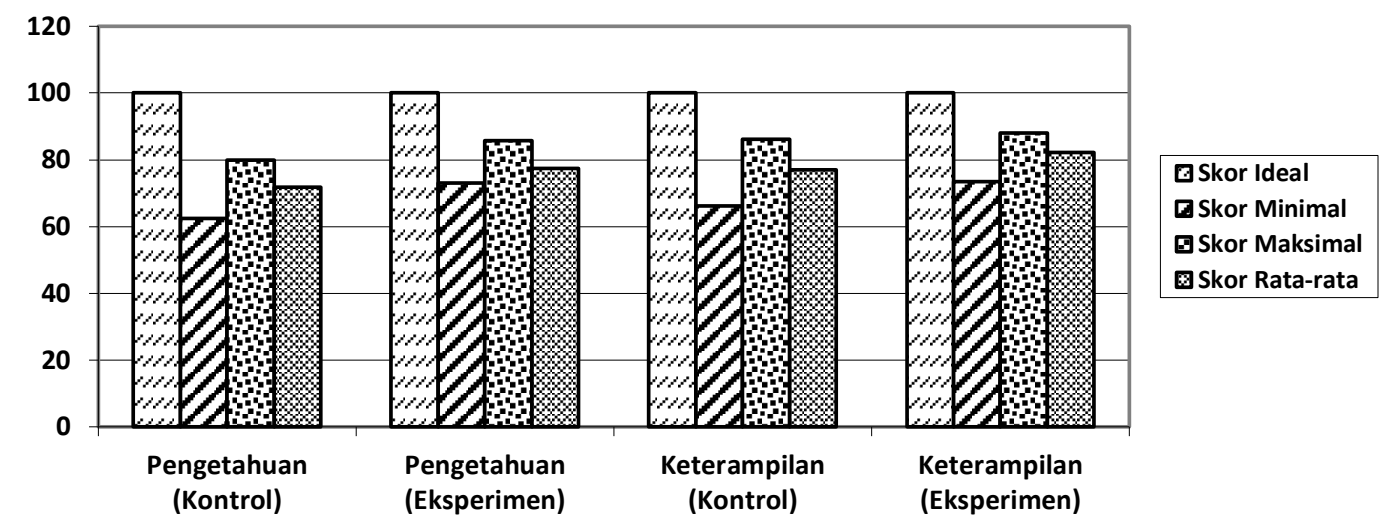

Gambar 1. Hasil skor Post $s$ Pengetahuan dan skor Keterampilan dalam pembelajaran Sains

Hasil analisis tanggapan mahasiswa PGSD pada perkuliah Sains mahasiswa PGSD dengan model belajar inkuiri secara pemodelan (kelompok eksperimen) dan secara konvensional (kelompok kontrol) disajikan pada gambar 2 di bawah ini.

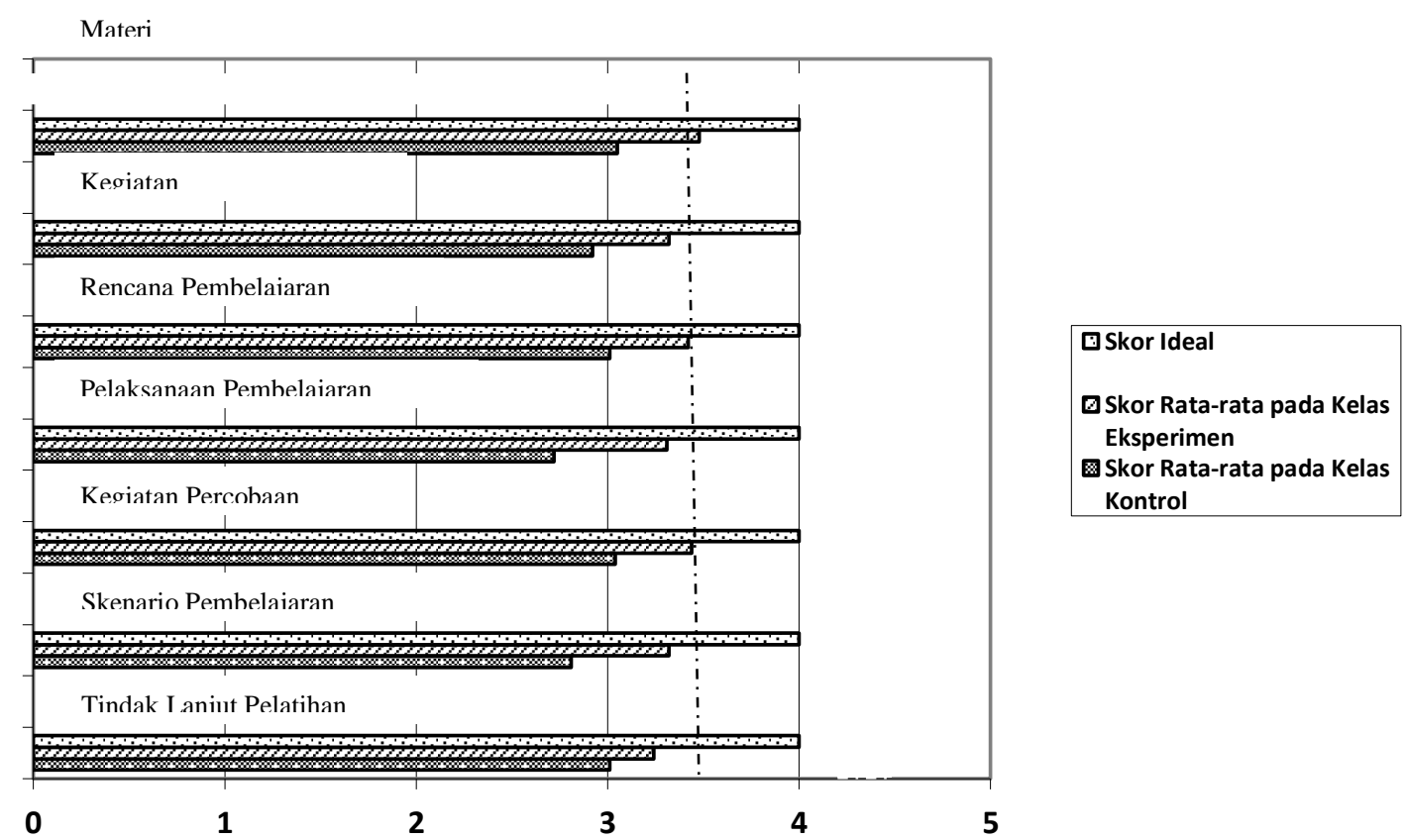

Gambar 2. Tanggapan mahasiswa pada perkuliah Sains mahasiswa PGSD pada pembelajaran model inkuiri secara pemodelan (kelompok eksperimen) dan secara konvensional (kelompok kontrol) 


\section{Pembahasan}

\section{1. kemampuan (pengetahuan dan keterampilan) inkuiri}

Setelah dilakukan penelitian, kemudian dilakukan uji normalitas, uji homogenitas dan uji-t.

Pada tabel 1, dengan menggunakan uji Kolmogrov Smirnov, hasil uji normalitas yang diperoleh menunjukkan bahwa kemampuan inkuiri mahasiswa PGSD memiliki skor yang lebih besar dari nilai $\alpha(0,05)$, untuk pengetahuan sebesar 0.687 (kelas control) dan sebesar 0.847 (kelas eksperimen), sedang untuk keterampilan sebesar 0.705 (kelas kontrol) dan 0.354 (kelas eksperimen), hal ini menunjukkan bahwa data kemampuan inkuiri mahasiswa PGSD dari dua kelas yang dijadikan sampel penelitian berdistribusi normal.

Tabel 1. Hasil perhitungan uji normalitas

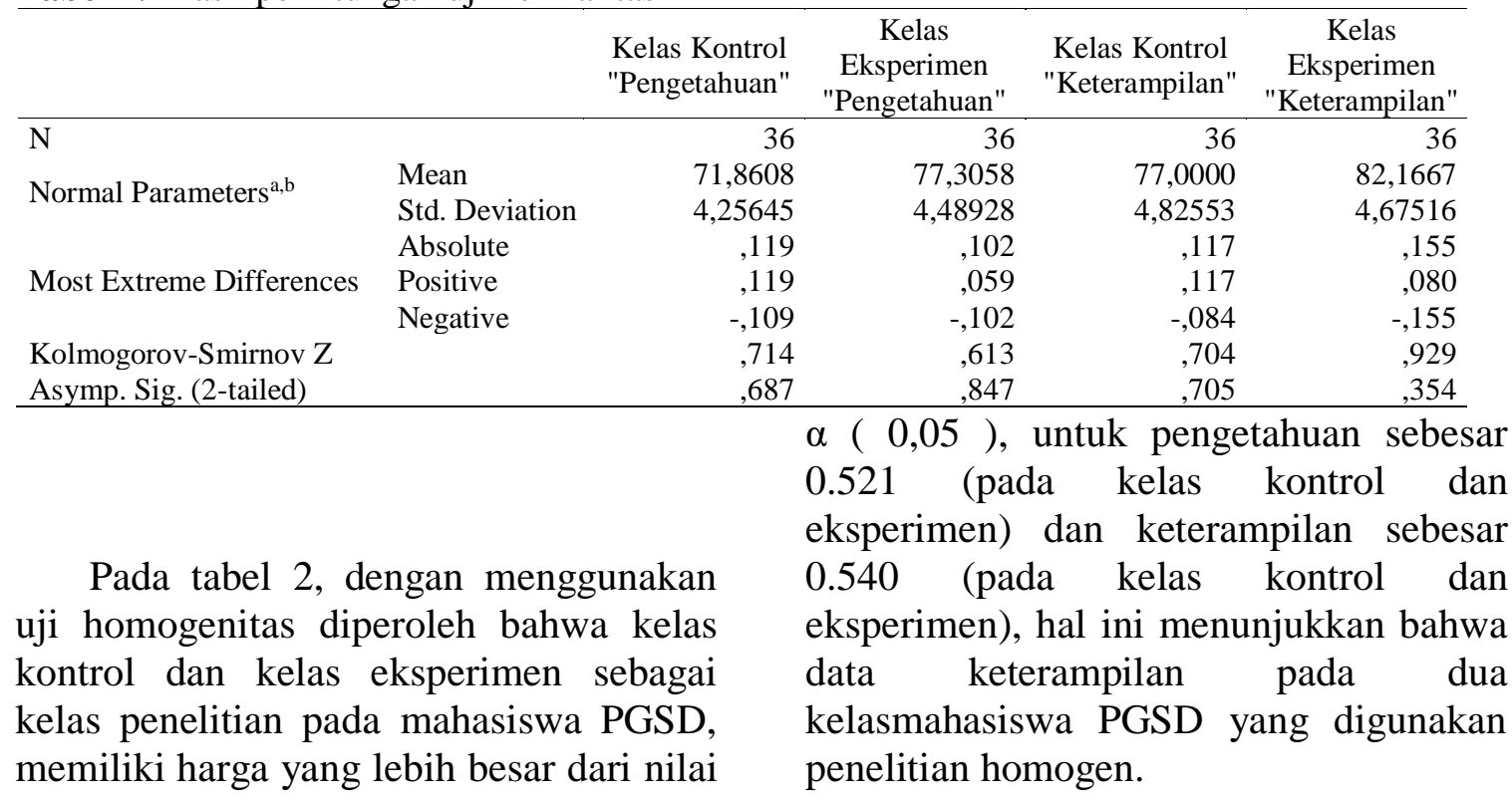

Tabel 2. Hasil perhitungan Homogenitas

\begin{tabular}{cccccccc}
\hline Pengetahuan pada kelas kontrol dan eks & \multicolumn{5}{c}{ Keterampilan pada kelas kontrol dan eks } \\
\hline Levene Statistic & df1 & df2 & Sig. & Levene Statistic & df1 & df2 & Sig. \\
, 416 & 1 & 70 &, 521 &, 374 & 1 & 70 &, 540 \\
\hline
\end{tabular}

Pada tabel 2, kolom Levene's Test for Equality of Varian sadalah kolom yang digunakan untuk melakukan uji kesamaan dua varians (homogenitas), kriteria uji yang digunakan, jika $\alpha$ (Sig.) > 0,05 , maka $\mathrm{H}_{\mathrm{o}}$ diterima. Hasil perhitungan
Sig. sebesar 0,521 dan ternyata lebih besar dari $\alpha(=0,05)$ ini berarti bahwa $\mathrm{H}_{\mathrm{o}}$ diterima, sehingga disimpulkan bahwa kedua populasi memiliki varians yang sama 
Tabel 3. Hasiluji kesamaan dua varians dan uji perbedaan dua rata-rata pengetahuan

\begin{tabular}{|c|c|c|c|c|c|c|c|c|c|c|}
\hline & & \multicolumn{2}{|c|}{$\begin{array}{l}\text { Levene's Test } \\
\text { for Equality of } \\
\text { Variances }\end{array}$} & \multicolumn{7}{|c|}{ t-test for Equality of Means } \\
\hline & & \multirow[t]{2}{*}{$\mathrm{F}$} & \multirow[t]{2}{*}{ Sig. } & \multirow[t]{2}{*}{$\mathrm{T}$} & \multirow[t]{2}{*}{ Df } & \multirow[t]{2}{*}{$\begin{array}{l}\text { Sig. (2- } \\
\text { tailed) }\end{array}$} & \multirow[t]{2}{*}{$\begin{array}{c}\text { Mean } \\
\text { Difference }\end{array}$} & \multirow[t]{2}{*}{$\begin{array}{l}\text { Std. Error } \\
\text { Difference }\end{array}$} & \multicolumn{2}{|c|}{$\begin{array}{l}\text { 95\% Confidence } \\
\text { Interval of the } \\
\text { Difference }\end{array}$} \\
\hline & & & & & & & & & Lower & Upper \\
\hline & $\begin{array}{l}\text { Equal } \\
\text { variances }\end{array}$ & ,416 &, 521 & $-5,281$ & 70 &, 000 & $-5,44500$ & 1,03106 & $-7,50138$ & $-3,38862$ \\
\hline Pengetahuan & $\begin{array}{l}\text { assumed } \\
\text { Equal } \\
\text { variances not } \\
\text { assumed }\end{array}$ & & & $-5,281$ & 69,802 & , 000 & $-5,44500$ & 1,03106 & $-7,50149$ & $-3,38851$ \\
\hline
\end{tabular}

Uji selanjutnya yang dilakukan adalah uji perbedaan dua rata-rata atau Uji-t dengan menggunakan program komputer diperoleh hasil Uji-t (tabel 2) pada kolom $t$-test for Equality of Means, Berdasarkan tabel 2 ternyata nilai Sig.(2tailed) kemampuan inkuiri mahasiswa PGSD sebesar 0,00, ini menunjukkan bahwa nilai Sig.(2-tailed) lebih kecil dari nilai $\alpha(0,05)$, artinya bahwa $\mathrm{H}_{1}$ diterima, yaitu rata-rata kemampuan inkuiri mahasiswa PGSD dalam pembelajaran sains secara inkuiri lebih tinggi dari ratarata kemampuan inkuiri mahasiswa
PGSD dalam pembelajaran sains secara konvensional.

Pada tabel 4, kolom Levene's Test for Equality of Varians adalah kolom yang digunakan untuk melakukan uji kesamaan dua varians (homogenitas), kriteria uji yang digunakan, jika $\alpha$ (Sig.) $>0,05$, maka $\mathrm{H}_{\mathrm{o}}$ diterima. Hasil perhitungan Sig. sebesar 0,538 dan ternyata lebih besar dari $\alpha(=0,05)$ ini berarti bahwa $\mathrm{H}_{\mathrm{o}}$ diterima, sehingga disimpulkan bahwa kedua populasi memiliki varians yang sama.

Tabel 4. Hasil Uji Kesamaan Dua Varians dan Uji Perbedaan Dua Rata-rata Keterampilan

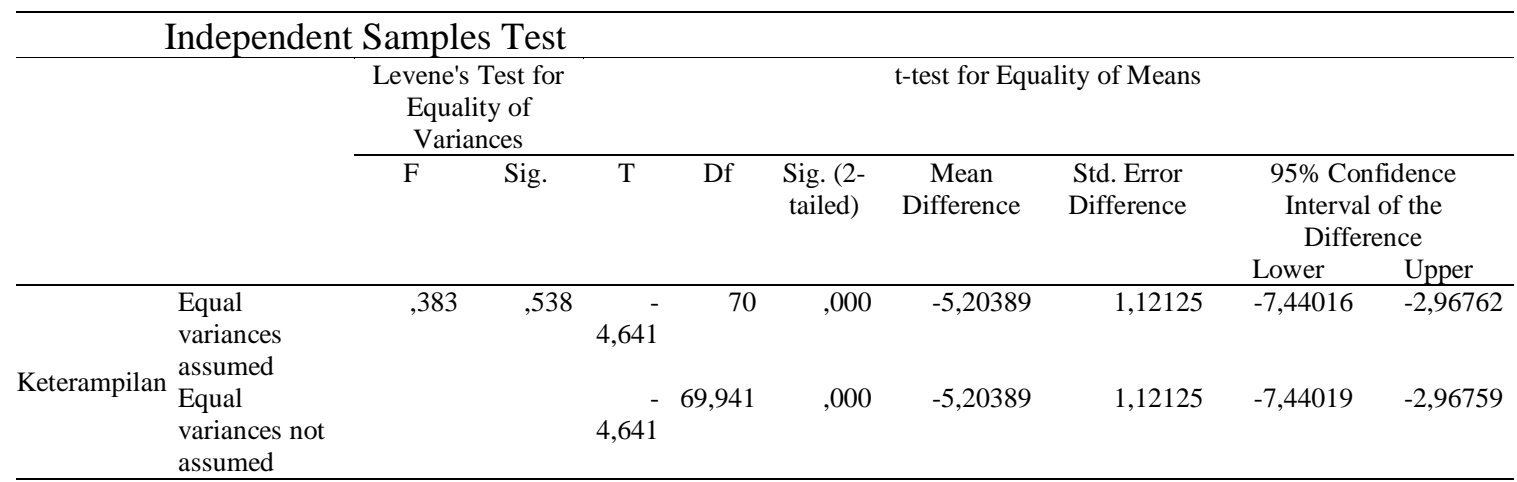

Uji selanjutnya yang dilakukan adalah uji perbedaan dua rata-rata atau Uji-t dengan menggunakan program komputer diperoleh hasil Uji-t (tabel 2)pada kolom t-test for Equality of Means, Berdasarkan tabel 2 ternyata nilai Sig.(2-tailed) kemampuan inkuiri mahasiswa PGSD sebesar 0,00, ini menunjukkan bahwa nilai Sig.(2-tailed) lebih kecil darinilai $\alpha(0,05)$, artinya bahwa $\mathrm{H}_{1}$ diterima, yaitu rata-rata kemampuan inkuiri mahasiswa PGSD dalam pembelajaran sains secara inkuiri lebih tinggi dari rata-rata kemampuan inkuiri mahasiswa PGSD dalam pembelajaran sains secara konvensional.

Berdasarkan perhitungan di atasdapat disimpulkan bahwa kemampuan inkuiri mahasiswa PGSD dalam pembelajaran sains model belajar inkuiri secara pemodelan memberikan rata-rata skor yang lebih berarti (tinggi) 
dibandingkan dengan kemampuan inkuiri mahasiswa PGSD dalam pembelajaran sains model inkuiri secara konvensional, dengan kata lain pembelajaran sains model inkuiri secara pemodelan signifikan lebih efektif dibandingkan dengan pembelajaran sains model inkuiri secara konvensional dalam meningkatkan kemampuan inkuiri mahasiswa PGSD. Seperti yang dingkapkan (Rustaman, 2005) bahwa kemampuan merancang dan melaksanakan kegiatan laboratorium fisika berbasis inkuiri bagi calon guru menunjukan peningkatan kemampuan merancang dan melaksankan kegiatan laboratorium.

Beberapa faktor yang menyebabkan mengapa pembelajaran model inkuiri dengan pemodelan lebih efektif dalam meningkatkan pengetahuan inkuiri mahasiswa PGSD dibandingkan dengan pembelajaran model inkuiri secara konvensional, seperti diungkapkan oleha (Ertikanto, 2015) bahwa penggunaan inkuiri oleh guru-guru akan meningkatkan kemampuan mengajar guru semakin baik, karena di dalam mengajar, guru secara tidak langsung juga selalu belajar. Mengajar sains memerlukan suatu metode yang melibatkan siswa dalam pembelajaran (Rustaman, 2005). Pembelajaran secara inkuiri dengan pemodelan memiliki beberapa keunggulan dibandingkan dengan konvensional. Diantaranya adalah mengutamakan proses (Ruiz-Primo, 2007) yang berisi antara lain: didalamnya terdapat proses: mengamati, mengumpulkan, mengklasifikasi dan melakukan eksperimen untuk menarik simpulan, dan mengkomunikasikan (Ertikanto, 2015). Dibandingkan dengan pembelajaran secara konvensional, yaitu pembelajaran yang banyak menginformasikan materi bersifat hafalan, mendengarkan guru menerangkan, sehingga menyebabkan hasil belajar sains menjadi rendah, mahasiswa yang mengalami pembelajaran inkuiri dikelompokkan dengan anggota kelompok yang beragam kemampuannya, ada mahasiswa yang berkemampuan tinggi, sedang, dan rendah. Pengelompokan semacam ini akan menyebabkan terjadinya transfer kemampuan antar mahasiswa yang terlibat pembelajaran, dan mahasiswa yang mengalami pembelajaran secara inkuiri dengan pemodelan, terlibat lebih aktif dalam pembelajaran, dengan terlibatnya mahasiswa secara aktif dalam pembelajaran menyebabkan konsentrasi mahasiswa dalam memahami konsepkonsep yang dipelajari menjadi lebih tinggi.

\section{Tanggapanmahasiswa PGSD terhadap Latihan Mengajar}

Tanggapan mahasiswa terhadap Kemampuan Inkuiri mengajar Sains pada perkuliahan Sains disajikan dalam gambar 2. Implementasi pelaksanaan latihan mengajar telah berjalan sesuai dengan jadwal yang telah ditentukan, sekalipun terdapat kendala-kendala kecil pada pelaksanaannya. Tanggapan mahasiswa PGSD terhadap pelaksanaan kegiatan mengajar dapat diuraikan sbb:

Pertama: Materi yang disajikan mendapat tanggapan yang positip, karena materi dalam kegiatan sesuaidengan kebutuhan mahasiswa PGSD dalam mengajar (Matson, 2006) untuk meningkatkan kemampuan inkuiri dalam pembelajaran sains. Kedua kelompok memberi tanggapan dengan skor yang berbeda, kelas eksperimen memberikan skor rata-rata sebesar 3,24, sedangkan kelas kontrol sebesar 3,01 (skor rata-rata ideal yang diharapkan sebesar 4,0). Kedua kelompok memberikan skor ratarata yang berbeda, karena memang kedua kelompok memperoleh ilmu secara langsung sesuai harapan masing-masing.

Kedua: Kegiatan mengajar yang dilaksanakan dalam perkuliahan mendapat tanggapan yang positip, karena kegiatan latihan sesuai dengan yang 
diharapkan untuk kebutuhan meningkatkan kemampuan inkuiri dalam pembelajaran sains (Cuevas, 2005). Kedua kelompok memberi tanggapan dengan skor yang berbeda, kelas eksperimen memberikan tanggapan dengan skor rata-rata sebesar 3,32, sedang kelas kontrol sebesar 2,81 (skor rata-rata ideal yang diharapkan sebesar $4,0)$.

Ketiga: Perencanaan pembelajaran yang dilaksanakan mendapat tanggapan yang positif, karena sesuai dengan kebutuhan di lapangan (Hermawan, 2014), Kedua kelompok memberi tanggapan dengan skor yang berbeda, kelas eksperimen memberikan skor ratarata sebesar 3,44, sedangkan kelas kontrol memberi tanggapan sebesar 3,04 (dengan skor rata-rata ideal yang diharapkan sebesar 4,0).

Keempat:Pelaksanaan pembelajaran mendapat tanggapan yang positif, karena kegiatan pelaksanaan pembelajaran dalam kegiatan sesuai dan dibutuhkan oleh guru-guru di lapangan (Joyce, 2001). Kedua kelompok memberi tanggapan yang berbeda, kelas eksperimen memberi tanggapan dengan skor rata-rata sebesar 3,31,sedangkan kelas kontrol memberi tanggapan dengan skor rata-rata sebesar 2,72 (dengan skor rata-rata ideal yang diharapkan sebesar 4,0). Kedua kelompok memberikan skor rata-rata berbeda, ini dapat dipahami karena dalam pelaksanaan pelatihan menggunakan pola yang berbeda, pada kelas eksperimen setelah setiap contoh pembelajaran dilanjutkan dengan sesi diskusi (dengan tiga contoh pelaksanaan pembelajaran), sedangkan pada kelas kontrol setelah tiga contoh pelaksanaan pembelajaran diberikan sekaligus, barudilanjutkan dengan sesi diskusi. Namun demikian, kedua kelompok tetap memperoleh kegiatan yang diharapkan sesuai dengan kebutuhan guru-guru.

Kelima: Kegiatan percobaan dalam latihan pembelajaran mendapat tanggapan yang positif, karena kegiatan percobaan yang diselenggarakan sesuai dengan kebutuhan (Pine, 2006). Kedua kelompok memberi tanggapan berbeda, kelas eksperimen memberikan tanggapan dengan skor rata-rata sebesar 3,42, sedangkan kelas kontrol sebesar 3,01 (dengan skor rata-rata ideal yang diharapkan sebesar 4,0). Kedua kelompok memberikan skor rata-rata berbeda, karena penyajian kegiatan pola pelatihan yang diterapkan berbeda, pada kelas eksperimen setelah contoh merancang percobaan dilanjutkan dengan sesi diskusi (ada tiga contoh kegiatan percobaan), sedangkan pada kelas kontrol setelah tiga contoh merancang kegiatan percobaan sekaligus diberikan, baru dilanjutkan sesi diskusi. Pola sajian pelatihan yang berbeda inilah yang kemungkinan menyebabkan tanggapan mahasiswa PGSD pada kelas eksperimen dan kelas kontrol menjadi berbeda.

Keenam: Skenario Pembelajaran yang dilaksanakan mendapat tanggapan yang positif, tampaknya sesuai dengan kebutuhandi lapangan (Dewi, 2015). Kedua kelompok memberi tanggapan berbeda, kelas eksperimen memberikan skor rata-rata sebesar 3,32, sedangkan kelas kontrol memberi tanggapan dengan skor rata-rata sebesar 2,92 (dengan skor rata-rata ideal yang diharapkan sebesar 4,0). Kedua kelompok memberi tanggapan dengan skor rata-rata yang berbeda, karena dalam pelaksanaan pelatihan memang berbeda, disamping kedua kelompok memperoleh kegiatan yang sesuai dengan harapan,juga berkontribusi terhadap peningkatan kemampuan inkuiri.

Ketujuh: Tindak lanjut Latihan sebagian mahasiswa PGSD memberi tanggapan positif (Capobianco B. \&., 2006). Kedua kelompok memberi tanggapan yang berbeda, kelas eksperimen memberi tanggapan dengan skor rata-rata sebesar 3,48, sedangkan kelas kontrol memberi tanggapan dengan 
skor rata-rata sebesar 3,05 (dengan skor rata-rata ideal yang diharapkan sebesar 4,0). Hasil analisis angket menyatakan bahwa kelompok mahasiswa belajar sains dengan model inkuiri secara pemodelan akan menerapkan pembelajaran demikian selanjutnya.

Kegiatan ini mendapat tanggapan positif dari kelompok mahasiswa PGSD, Kelompok kelas eksperimen memberi tanggapan yang positif. Kelas eksperimen memberi tanggapan kegiatan ini dengan skor rata-rata sebesar 3,50, sedangkan kelas kontrol memberi tanggapan dengan skor rata-rata sebesar 3,06 (dengan skor rata-rata ideal yang diharapkan sebesar 4,0). Sekalipun kedua kelompok memberikan skor rata-rata berbeda, tetapi secara akademik menunjukkan akan keperluan kelompok mahasiswa PGSD dalam meningkatkan kemampuan inkuiri pada pembelajaran sains, baik itu kelompok eksperimen maupun kelompok kontrol, yang penting adalah mahasiswa PGSD berharap supaya kegiatan latihan mengajar atau latihan sejenis ini dapat dilaksanakan secara periodik dan berkesinambungan.

\section{SIMPULAN DAN SARAN}

Kemampuan inkuiri mahasiswa PGSD setelah mengikuti perkuliah Sains SD dengan model belajar inkuiri secara pemodelan, signifikan lebih tinggi dibandingkan dengan model belajar inkuiri secara konvensional. Kelompok eksperimen lebih tampak antusias, dan memberikan tanggapan positif dengan skor rerata yang lebih tinggi, dan mahasiswa PGSD berharap matakuliah yang berlabel SD dapat dilaksanakan dengan model belajar inkuiri secara pemodelan.

\section{DAFTAR PUSTAKA}

Aprilia, L., \& Mulyaningsih, S. (2014). Penerapan Perangkat Pembelajaran Materi Kalor Melalui Pendekatan Saintifik Dengan Model
Pembelajaran Guided Discovery Kelas X SMA. Skripsi tidak dipublikasikan. Surabaya: Universitas Negeri Surabaya.

Arikunto, S. (2008). Evaluasi Program Pendidikan.Jakarta: Bumi Aksara.

Capobianco, B., \& Lehman, J. (2006). Integrating technology to foster inquiry in an elementary science methods course: A case study of one teacher educator's initiatives in a PT3 project. Journal of Computers in Mathematics and Science Teaching, 25(2), 123-146

Cuevas, P., Lee, O., Hart, J., \& Deaktor, R. (2005). Improving science inquiry with elementary students of diverse backgrounds. Journal of Research in Science Teaching, 42(3), 337-357.

Dewi, P S., dan Rochintaniawati, D. (2015). Implementasi Pendekatan Saintifik Terhadap Proses Aktivitas Guru dan Siswa pada Pembelajaran IPA Terpadu. ITB. Prosiding Simposium Nasional Inovasi dan Pembelajaran Sains. ISBN: 978602-19655-8-0.

Ertikanto, C., Wahyudi, I., \& Viyanti, V. (2015). Increasing Teachers Inquiry Ability With Training Inquiry Ability Programme And Teaching Science. Jurnal Pendidikan IPA Indonesia, 4(2).

Ertikanto, C., Viyanti, V., \& Wahyudi, I. (2015). Keefektifan Pengetahuan Inkuiri Guru Sekolah Dasar Kota Bandar Lampung Dalam Pembelajaran Sains. Prosiding SNPS (Seminar Nasional Pendidikan Sains) (Vol. 2, Pp. 106116).

Hermawan, A. A. (2014). Pengembangan Perangkat Pembelajaran Kurikulum 2013 Melalui Pendekatan Scientific pada Materi Alat Optik untuk 
Melatihkan Sikap Ilmiah Siswa Kelas X Sman 3 Surabaya. Inovasi Pendidikan Fisika, 3(3).

Education, A. (2004). Focus on inquiry: A teacher's guide to implementing inquiry-based learning. Alberta, Canada: Author.

Joyce, B., Weill, M., \& Colhoun, E. (2001). Models of Teaching. $6^{\text {th }}$ edition. Boston: Allyn an Bacon.

Marx, R. W., Blumenfeld, P. C., Krajcik, J. S., Fishman, B., Soloway, E., Geier, R., \& Tal, R. T. (2004). Inquiry-based science in the middle grades: Assessment of learning in urban systemic reform. Journal of research in Science Teaching, 41(10), 1063-1080.

Matson, J. O., \& Parsons, S. (2006). Misconceptions about the nature of science, inquiry-based instruction, and constructivism: Creating confusion in the science classroom. Electronic Journal of Literacy through Science, 5(6), 1-10.

National Research Council. NRC.(2000). Inquiry and the National Science Education Standards: A Guide for Teaching and Learning.

Pine, J., Aschbacher, P., Roth, E., Jones, M., McPhee, C., Martin, C., ... \& Foley, B. (2006). Fifth graders' science inquiry abilities: A comparative study of students in hands-on and textbook curricula. Journal of research in science teaching, 43(5), 467-484.

Nasional, D. P. (2003). Kurikulum 2004. Jakarta: Depdiknas.

Ruiz-Primo, M. A., \& Furtak, E. M. (2007). Exploring teachers' informal formative assessment practices and students' understanding in the context of scientific inquiry. Journal of research in science teaching, 44(1), 57-84.

Rustaman, N. Y. (2005, July). Perkembangan penelitian pembelajaran berbasis inkuiri dalam pendidikan sains. In Makalah dipresentasikan dalam Seminar Nasional II Himpunan Ikatan Sarjada dan Pemerhati Pendidikan IPA Idonesia Bekerjasama dengan FPMIPA. Universitas Pendidikan Indonesia, Bandung (pp. 22-23).

Saregar, A., Sunarno, W., \& Cari, C. (2013). Pembelajaran Fisika Kontekstual Melalui Metode Eksperimen Dan Demonstrasi Diskusi Menggunakan Multimedia Interaktif Ditinjau Dari Sikap Ilmiah Dan Kemampuan Verbal Siswa. Inkuiri, 2(02). 